\title{
Bisnis Transportasi dalam Pusaran Globalisasi
}

Mutimatun Ni'ami

Fakultas Hukum, Universitas Muhammadiyah Surakarta, Email: niami_mutimatun@gmail.com

\begin{tabular}{l}
\hline Info Artikel \\
\hline \\
Keywords: \\
Online Taxi; Conventional \\
Taxi; Legal. \\
\\
\\
\\
Pata kunci: \\
Online; \\
Taksi Taksi \\
Konvensional; Hukum. \\
Corresponding Author: \\
Mutimatun Ni'ami, \\
E-mail: \\
niami_mutimatun@gmail.com \\
\hline
\end{tabular}

\begin{abstract}
This study aims to examine the differences between conventional taxis and online taxis and whether the existing legal regulations are sufficient to regulate the two modes of transportation. The author's curiosity comes from seeing the past when taxis were considered a luxury means of transportation that people rarely use except for emergencies, so city buses and public transportation become the choice of citizens. The choice that was "forced" to be taken considering the low cost and far coverage. Now, when online taxis offer low costs and easy access, the means of transportation that have become "gods" have fallen. The drivers gasped, the transportation entrepreneurs were distracted to finance their business empire and the passengers were no longer greeted by buses and public transportation. This research is a sociological legal research which makes a phenomenon that exists in society and its influence on existing legal rules. The research results show that the difference between conventional taxis and online taxis lies in the amount of tariff, standardization of services, determination of routes and special features and legal protection. The government needs to be firm in regulating the existence of online transportation, given the potential for conflict over disparity in tariff differences and the importance of legal protection for drivers and passengers in driving safety.
\end{abstract}

\begin{tabular}{l} 
Abstrak \\
\hline Penelitian ini bertujuan untuk mengkaji terkait perbedaan antara taksi \\
konvensional dengan taksi online dan apakah aturan hukum yang ada saat \\
ini sudah cukup memadai mengatur kedua moda transportasi tersebut. \\
keingin tahuan penulis terseut berasal dari melihat masa lalu ketika taksi \\
dianggap alat transportasi mewah yang jarang orang menggunakannya \\
kecuali karena keadaan darurat, maka bis kota dan angkot menjadi pilihan \\
warga masyarakat. Pilihan yang "terpaksa" diambil mengingat biaya yang \\
murah dan daya jangkau yang jauh. Sekarang, ketika taksi online \\
menawarkan biaya murah dan kemudahan akses maka berjatuhanlah alat \\
transportasi yang selama ini seperti menjadi "dewa". Para sopir tersentak, \\
penguasaha angkutan kelimpungan membiayai kerajaan bisnisnya dan \\
jadilah bis dan angkot tersisih tak disapa lagi penumpangnya. Penelitian ini \\
merupakan penelitian hukum sosiologi yang menjadikan fenomena yang ada \\
pada masyarakat dan pengaruhnya terhadap aturan hukumyang ada. \\
Adapun hasil penelitian menunjuakan bahwa Perbedaan antara taksi \\
konvensional dan taksi online terletak pada besaran tariff, standarisasi \\
layanan, penentuan trayek dan ciri khusus serta perlindungan hukum. \\
Diperlukan segera ketegasan Pemerintah mengatur keberadaan transportasi \\
online, mengingat potensi konflik atas disparitas perbedaan tariff dan \\
pentingnya perlindungan hukum bagi pengemudi dan penumpang dalam \\
keselamatan berkendara.
\end{tabular}




\section{Pendahuluan}

Pada dasarnya, "kondisi awal" struktur masyarakat selalu berada pada kondisi yang kurang imbang. Di satu sisi ada yang dominan, dan di sisi yang lain ada kelompok yang terpinggirkan. Untuk mewujudkan tatanan masyarakat yang beradab maka ketimpangan-ketimpangan structural mestilah ditata ulang dalam pola keseimbangan yang proporsional. Hukum mestilah difungsikan untuk menata perubahan secara progresif. Dari sinilah muncul teori Pound tentang law as a tool of social engineering. Dalam upaya mewujudkan ide tersebut, maka hukum harus berperan "menata kepentingan-kepentingan yang ada dalam masyarakat." Kepentingan-kepentingan itu harus ditata sedemikian rupa agar tercapai keseimbangan yang proporsional. Manfaatnya adalah terbangunnya suatu struktur masyarakat yang secara maksimum akan mencapai kepuasan dan seminimum mungkin menghindari benturan dan pemborosan. ${ }^{1}$

Hukum dapat bermakna jika dalam pelaksanaannya legislatif dibantu oleh keberadaan hakim sebagai pemikir pembantu yang tidak hanya menaruh perhatian pada kata-kata dan perintah. Para hakim haruslah mengerti keinginan-keinginan pembuat undang-undang dan mengungkapkan penilaian-penilaian hukum dalam keadaan umum maupun dalam keadaan khusus dalam hal menyeimbangkan kepentingan-kepentingan yang dipertaruhkan dalam sebuah kasus. Hal inilah yang dikenal dengan Interessen jurisprudenz. ${ }^{2}$ Pound mengusulkan agar para ahli hukum beraliran sosiologis perlu lebih memperhitungkan fakta sosial dalam pekerjaannya, apakah pembuatan hukum, penafsiran atau penerapan peraturan. Bagi Pound, antara hukum dan masyarakat terdapat hubungan yang fungsional. Hukum sebagai sarana social engineering, bermakna penggunaan hukum secara sadar untuk mencapai tertib atau keadaan masyarakat sebagaimana dicita-citakan. Hukum tidak lagi dilihat sekedar sebagai tatanan penjaga status quo, tetapi juga diyakini sebagai sistem pengaturan untuk mencapai tujuan-tujuan tertentu secara terencana.

Berangkat dari pandang di atas apabila kita melihat masa lalu ketika taksi dianggap alat transportasi mewah yang jarang orang menggunakannya kecuali karena keadaan darurat, maka bis kota dan angkot menjadi pilihan warga masyarakat. Pilihan yang "terpaksa" diambil mengingat biaya yang murah dan daya jangkau yang jauh. Masyarakat harus menerima ketika harus berada dalam suasana ruang yang sumpek, panas, bau dan diperlakukan layaknya "ikan asin" yang berdesak-desakan ditegah himpitan copet dan pengamen. Ketika sempat muncul keluhan dari penumpang, maka supir akan menukas "kalau nggak mau kayak gini ya naik taksi aja". Sekarang, ketika taksi online menawarkan biaya murah dan kemudahan akses maka berjatuhanlah alat transportasi yang selama ini

${ }^{1}$ Roscoe Pound "Contemporary Jurisdic Theory" dalam Bernard L Tanya, Teori Hukum, Genta Publishing, hlm. 139-140

${ }^{2}$ Ibid, hlm. 144 
seperti menjadi “dewa”. Para sopir tersentak, penguasaha angkutan kelimpungan membiayai kerajaan bisnisnya dan jadilah bis dan angkot tersisih tak disapa lagi penumpangnya.

Memang perputaran roda perubahan dan peradaban memang terasa sangat cepat. Hanya dalam waktu 2 tahun sejak muncul secara luas banyak perusahaan taksi konvensional yang terpaksa harus "merumahkan" karyawannya. Disparitas tarif batas atas dan batas bawah dalam persaingan taksi online dan taksi konvensional dituding menjadi biang keladi merosotnya peminat pada pemain lama dalam bisnis angkutan ini. Pemerintah dibuat bingung dengan regulasi yang dibutuhkan. Ketika peraturan muncul, dalam jangka waktu yang pendek, reaksi masyarakat langsung muncul beragam. Pengemudi taksi konvensional tentu saja mendukung, agar perbedaan diantara mereka dapat tereduksi, namun taksi online menolak aturan tersebut dengan berbagai macam alasan sampai akhirnya mereka mengajukan yudisial review ke Mahkamah Agung dan berhasil. Fenomena ini menarik untuk dikaji, carut marut keberadaan taksi online yang dibutuhkan tapi masih dianggap illegal. Terlalu dominankah pemilik modal taksi ataukah terlalu lemahnya penegakan hukum oleh pemerintah.

Padahal bila melihat konsep mengenai pergeseran dan perkembangan peran negara telah terjadi sebagai akibat proses modernisasi dan demokratisasi sistem pemerintahan negara. Paham negara mengalami perkembangan dari political state menjadi legal state dan akhirnya welfare state. Ketiga faham tersebut semuanya memanfaatkan kekuasaan yang dimiliki negara sebagai penentu kehendak terhadap aktivitas rakyat yang dikuasainya. Negara welfare state muncul sebagai jawaban atas ketimpangan sosial yang terjadi dalam sistem ekonomi liberal. Pada faham negara kesejahteraan, negara memiliki freis ermessen yaitu kebebasan untuk turut serta dalam seluruh kegiatan sosial, politik, ekonomi dengan tujuan akhir menciptakan kesejahteraan umum bestuurzorg. Dahulu, pemerintah memiliki peran sentris dalam mengatur rakyatnya. Meskipun tidak mengatur secara total, namun aturan yang dibuat dan penegakan hukumnya dapat dilaksanakan dengan mudah mengingat kendali pemerintah atas rakyatnya masih besar.

Seiring waktu, proses modernisasi mengurangi kewenangan pemerintah untuk mengatur warga negaranya. Misalnya dalam transportasi online, pemerintah tidak mampu lagi mengatur transportasi sebagaimana dahulu. Ketika moda transportasi umum hanya boleh jika memiliki izin, bercirikan plat kuning dan melakukan uji KIR secara berkala. Melalui investasi saat ini, pemodal besar dipersilahkan memasuki Indonesia dengan pangsa pasar yang sangat besar. Pemain lama yang taat membayar pajak, mengikuti izin dengan patuh harus mampu bersaing dengan pemodal besar yang seringkali melakukan "aksi bakar duit " dengan rangka promosi. Pemerintah harus memaksa diri atau terpaksa untuk merubah dirinya dari awalnya sebagai penguasa dari political state menjadi legal state hingga pada akhirnya menjadi welfare state. Negara kesejahteraan adalah suatu bentuk pemerintahan demokratis yang menegasakan bahwa negara bertanggungjawab 
terhadap kesejahteraan rakyat yang minimal, bahwa pemerintah harus mengatur pembagian kekayaan negara agar tidak ada rakyat yang kelaparan. ${ }^{3}$

Dalam bidang ekonomi, ada empat fungsi negara, yaitu sebagai penjamin (provider) kesejahteraan rakyat, negara sebagai pengatur (regulator), negara sebagai pengusaha (entrepreneur) atau menjalankan sektor-sektor tertentu melalui Badan Usaha Milik Negara (BUMN), dan negara sebagai wasit (umpire) untuk merumuskan standar-standar yang adil mengenai sector ekonomi termasuk perusahaan negara (state corporation). ${ }^{4}$ Fungsi negara seperti yang dikatakan oleh Friedmann tersebut menunjukkan bahwa sebenarnya dalam paham negara kesejahteraan, negara boleh campur tangan dalam bidang perekonomian.

Secara historis konstitusional, dapat dibuktikan bahwa negara hukum Indonesia menganut paham negara kesejahteraan. Adanya demokrasi ekonomi yang menjadi ciri khas dari negara kesejahteraan tercermin dalam Penjelasan Pasal 33 UUD 1945. Pilihan Indonesia untuk berpaham negara kesejahteraan telah menjadi tekad bulat. Di samping sebagai negara kesejahteraan, Indonesia juga mendeklarasikan dirinya sebagai negara hukum. Sebagai negara yang menganut paham negara kesejahteraan, maka negara dapat menggunakan hukum sebagai salah satu sarana untuk mengatur dan menyelenggarakan serta menjamin kesejahteraan rakyatnya. Oleh karena itulah, diperlukan pembangunan sistem hukum nasional yang akan dipakai untuk mendukung pemenuhan tanggungjawab tersebut. Melalui penulisan makalah ini, penulis akan mencoba menjelaskan dan memaparkan secara singkat mengenai perbedaan yang signifikan antara taksi konvensional dan taksi online dan apakah aturan hukum taksi online telah mampu mewadahi keberadaannya.

\section{Hasil dan Pembahasan}

\section{Perbedaan antara Taksi Konvensional (KOSTI SOLO) dan Taksi Online (GO- CAR)}

Koperasi Sopir Transportasi Solo (KOSTI SOLO) yang kantornya berada di Jl. Sumpah Pemuda No. 145 Mojosongo, Jebres, Kota Surakarta, Jawa Tengah 57127. Koperasi Sopir Transportasi Solo (KOSTI SOLO) merupakan koperasi yang bergerak dalam bidang jasa transportasi darat, dalam hal ini kosti solo menyediakan jasa yaitu taksi atau transportasi perkotaan roda empat yang membantu masyarakat dalam melakukan dan menjalankan aktivitas seharihari. ${ }^{5}$ Kosti berdiri mempunyai tujuan untuk memberikan pelayanan terbaik kepada masyarakat daerah Surakarta dan sekitarnya dengan mengikuti perkembangan ekonomi dan kemajuan teknologi yang membantu masyarakat

${ }^{3}$ RMAB Kusuma, Negara Kesejahteraan dan Jaminan Sosial, Jurnal Konstitusi, Vol 3, Februari 2006, Mahkamah Konstitusi, Jakarta, 2006, hlm. 160

4 Wolfgang Friedmann, The State and The Rule of Law in a Mixed Economy (London: Stevens and sons, 1971) hlm 3

${ }^{5}$ Wawancara dengan Pengelola Koperasi Sopir Transportasi Indonesia, Desember 2018 
untuk mempermudah memperpendek jarak tempuh penumpang sehingga penumpang bisa sampai ketempat tujuan tepat waktu, selain hal tersebut dengan berdirinya kosti ini juga mempunyai tujuan khusus untuk mensejahterakan anggota koperasinya itu sendiri.

Kosti hadir untuk memberikan pelayanan kepada masyarakat dalam hal transportasi agar memudahkan masyarakat untuk menempuh perjalanan ke tempat tujuan dengan nyaman, aman dan baik, dalam hal ini taksi kosti dalam penentuan tarif menggunakan argometer sehingga penumpang dapat membayarkan sesuai dengan jumlah yang tertera pada argometer taksi kosti tersebut. Bahwa dalam hal penentuan tarif menggunakan argometer terdapat 2 (dua) cara perhitungan, yaitu berdasarkan waktu dan juga berdasarkan jarak, di kosti solo sendiri menetapkan tarif dengan argometer tarif PER/KM sejumlah Rp 3.750,- atau sekitar Rp 375,- per 100M.

Koperasi Sopir Transportasi Solo (Kosti Solo) ini menggunakan sistem Owner Operator System yaitu dimana merupakan suatu sistem pengelolaan kosti solo dengan menjadikan driver atau sopir sebagai pengelola armada dan juga mengoperasikan armada atau taksi kosti solo itu sendiri, dan nantinya taksi yang mereka kelola akan menjadi milik mereka sendiri. Owner Operator System Kosti Solo ini memang berbeda dengan perusahaan-perusahaan yang lain dan yang pada umumnya, bahwa dimana perusahaan sebagai pemilik armada atau taksi sedangkan driver sebagai pekerja yang mengoperasionalkannya. Kosti solo selalu memberikan pelayanan yang terbaik bagi anggotanya, dimana dalam hal ini kosti memberikan kemudahan dan fasilitas bagi anggotanya, antara lain:

a. Seluruh driver di ikutkan dalam asuransi atau BPJS.

b. Adanya fasilitas perbaikan dan perawatan armada yang mengalami kerusakan oleh bengkel Kosti Solo yang buka selama 24 jam.

c. Adanya pengelolaan dana setoran dari driver oleh pihak kosti yang nantinya digunakan untuk berbagai hal yaitu perawatan, BPJS, administrasi kosti dan juga perbankan.

d. Pihak Kosti membantu driver untuk mendapatkan penumpang dengan penyediaan order melalui call center kosti.

Para driver di KOSTI SOLO ini memperoleh pembiayaan melalui Bank Jateng dalam memberikan armadanya. Pembayaran atau angsuran kepada Bank Jateng seluruhnya merupakan tanggung jawab pihak kosti, dimana dalam hal ini driver tidak berhubungan langsung dengan Bank Jateng dan driver membayar atau memberikan uang setoran kepada pihak kosti setelah itu pihak kosti lah yang akan membayarkannya kepada pihak bank. Pihak kosti memiliki hak untuk menerima dan mendapatkan uang setoran dari driver, selain itu pihak kosti juga memiliki kewajiban yaitu dimana pihak kosti harus mengurus armada dan driver misalnya apabila armada mogok dijalan maka pihak kosti akan menjemput armada tersebut apabila membutuhkan untuk di derek karena pihak 
kosti memiliki bengkel yang sistem kerjanya 24 jam yang di bagi menjadi 3 shift, selain itu pihak kosti juga berkewajiban untuk mengurus semua pembayaran pembiayaan kepada pihak perbankan, dan juga berkewajiban memfasilitasi driver agar bisa mendapatkan order dijalanan dengan nyaman dan juga melindungi lembaga koperasi sopir transportasi solo (kosti solo) agar berjalan dengan normal, baik (baik dalam hal karyawan, anggota, keuangan dan lain sebagainya) dan sesuai dengan tujuan koperasi tersebut.

Jangka waktu yang diberikan kepada driver yang telah melakukan atau sepakat dalam perjanjian yaitu 5 (lima) tahun untuk pembayaran armada tersebut kepada pihak kosti. Jadi driver yang telah melakukan perjanjian diberikan jangka waktu 5 (lima) tahun untuk melunasi pembayaran armada tersebut kepada pihak kosti, dimana apabila driver tersebut tidak dapat melunasi dalam waktu yang telah di tentukan driver tersebut dapat melakukan pengajuan perpanjangan waktu pelunasan kepada pihak kosti. Dalam hal driver yang diberikan untuk melakukan perjanjian tersebut dan mendapatkan armada haruslah telah menjadi anggota koperasi sopir transportasi solo (kosti solo) minimal 2 (dua) tahun dan harus mengikuti kegiatan koperasi seperti halnya rapat, upacara dan lain sebagaianya. Selain hal tersebut anggota kosti tersebut juga dilihat dari setorannya, apakah driver tersebut dianggap mampu dan mempunyai riwayat yang baik dalam hal setoran dan menjadi anggota koperasi untuk selanjutnya diberikan armada kepada driver tersebut.

Mengenai pembiayaan dalam hal ini yang bertanggung jawab atas segala resiko pembayaran, angsuran atau pelunasan adalah pihak kosti, jadi apabila terjadi macet dalam hal pembayaran di perbankan maka yang menanggung adalah pihak kosti, jadi dalam hal pembayaran kepada pihak bank ini anggota atau driver tidak mendapatkan beban atau tidak bertanggung jawab, karena anggota atau driver tidak berhubungan secara langsung dengan pihak bank dan yang berhubungan langsung dengan perbankan adalah pihak kosti. Total harga sewa yang diberikan oleh Kantor Kosti kepada anggota Kosti sesuai dengan pinjaman di Bank dan dikenakan tambahan bunga sebesar 0,5\%.

Namun pihak kosti mempunyai aturan kepada anggota atau driver, dimana setiap bulannya ada cash flow atau arus kas seperti laporan keuangan apakah saldonya minus atau plus dan ketika saldonya minus dan itu melebihi Down Payment atau DP dari yang dibayarkan pihak kosti, maka armada tersebut akan ditarik oleh pihak kosti. Misalkan dp tersebut adalah 30 juta kemudian dalam beberapa bulan atau tahun mereka mengalami minus yang mungkin disebabkan karena setoran kurang atau perawatan yang tinggi dan minus tersebut melebihi 30 juta maka secara otomatis armadanya akan ditarik oleh pihak kosti dan driver tetap menjadi anggota kosti tetapi menjadi driver cadangan dan tidak mempunyai armada lagi, armada yang telah ditarik tersebut akan diberikan kepada anggota yang nilainya baik atau bagus dalam hal setoran dan lain sebagainya. 
Dalam hal pembiayaan ini pihak kosti dan driver memiliki hak dan kewajiban. Driver memiliki kewajiban untuk melakukan setoran yang jumlahnya sudah ditentukan oleh pihak kosti setoran dalam hal ini telah mencakup biaya perawatan, bpjs, administrasi kosti dan juga perbankan, driver wajib melakukan setoran setiap harinya dan apabila driver tersebut selama 3 hari sampai 5 hari tidak setor maka akan di panggil atau di datangi oleh pihak kosti dan apabila hal tersebut masih terus berlanjut maka pihak kosti akan memberikan surat peringatan, yaitu peringatan pertama dengan jangka waktu 3 bulan selanjutnya peringatan kedua dengan jangka waktu 3 bulan dan peringatan ketiga dengan jangka waktu 3 bulan apabila driver tidak setor setelah peringatan ketiga maka armada tersebut akan ditarik. Selain kewajiban tersebut, driver memiliki hak yaitu untuk mendapatkan armada tersebut dan setiap driver di kosti di ikutkan BPJS yang mana hal ini sesuai dengan aturan pemerintah.

Pihak kosti memiliki hak untuk menerima dan mendapatkan uang setoran dari driver, selain itu pihak kosti juga memiliki kewajiban yaitu dimana pihak kosti harus mengurus armada dan driver misalnya apabila armada mogok dijalan maka pihak kosti akan menjemput armada tersebut apabila membutuhkan untuk di derek karena pihak kosti memiliki bengkel yang sistem kerjanya 24 jam yang di bagi menjadi 3 shift, selain itu pihak kosti juga berkewajiban untuk mengurus semua pembayaran pembiayaan kepada pihak perbankan, dan juga berkewajiban memfasilitasi driver agar bisa mendapatkan order dijalanan dengan nyaman dan juga melindungi lembaga koperasi sopir transportasi solo (kosti solo) agar berjalan dengan normal, baik (baik dalam hal karyawan, anggota, keuangan dan lain sebagainya) dan sesuai dengan tujuan koperasi tersebut.

Dalam hal pembiayaan di Koperasi Sopir Transportasi Solo (KOSTI SOLO) mengalami beberapa kendala atau keadaan yang tidak sesuai dengan yang telah di rencanakan, misalnya pihak kosti telah menetapkan bahwa target setoran perbulannya dari driver ke pihak kosti sekian, namun di tahun 2018 ini target tersebut tidak dapat terlampaui atau tercapai. Hal ini merupakan kendala atau hambatan yang dialami oleh pihak kosti dimana setoran yang telah di target tidak masuk dan otomatis kosti terbebani untuk membayar perbankan dan kosti harus atau berkewajiban untuk menutupi kekurangan pembayaran tersebut. Selain itu, banyaknya transportasi online dilapangan sehingga pasar atau operasi plat kuning tergerus oleh plat hitam dan sehingga menyebabkan driver kosti setorannya berkurang dan membuat berat atau beban untuk membayar bank karena pada dasarnya kosti mengandalkan setoran anggota atau driver yang dimana sekarang setoran berkurang dan target setorannya tidak tercapai atau terlampaui. Keadaan menurunnya setoran ini mulai terjadi pada awal pertengahan tahun 2017, namun pihak kosti masih dapat mengatasi tetapi pada tahun 2018 ini setoran menurun dan merupakan tahun terberat bagi kosti, dari 230 armada yang ada di kosti sudah ada 5 yang lunas dan menjadi plat hitam, 
namun dengan keadaan yang seperti sekarang ini pihak kosti belum bisa melakukan peremajaan karena situasi yang sekarang dan pihak kosti tidak berani memberikan kredit kepada anggota di tahun 2018 ini, dimana seharusnya setelah mendapat plat hitam maka driver tersebut diberi armada baru lagi tetapi dengan keadaan yang sekarang ini pihak kosti tidak berani memberikan peremajaan lagi kepada anggota atau driver.

Keadaan yang dialami pihak kosti sekarang ini membuat pihak kosti harus menemukan suatu solusi agar kosti masih bisa bertahan salah satu solusinya adalah dengan mengurangi biaya-biaya seperti biaya karyawan, dimana banyak karyawan kosti yang di phk karena beban yang banyak mulai tahun 2017 beberapa karyawan di phk dan yang paling banyak terkena phk pada tahun 2018 yang semula karyawan kosti berjumlah 80 karyawan dan sekarang menjadi sekitar 50 karyawan. Sebelum kendala atau hambatan ini terjadi setiap driver bisa melakukan setoran atau mendapatkan penghasilan sebanyak 250 ribu tetapi sekarang setiap driver hanya mendapatkan sekitar 100 ribu sampai dengan 150 ribu saja. Dari sekitar 225 armada yang beroperasi hanya sekitar 10\% sampai dengan 20\% karena banyak driver yang tidak kuat dengan keadaan yang sekarang dan akhirnya memutuskan untuk keluar, driver yang keluar merupakan driver yang belum melakukan kontrak perjanjian. Dulu jadwal operasional masing-masing driver adalah 2.1 yaitu dimana 2 hari masuk dan 1 hari libur, dengan banyaknya driver yang sudah tidak beroperasi akhirnya para driver yang msih bertahan jadwal operasionalnya adalah satu minggu masuk terus hanya satu atau dua hari mereka libur hal ini juga karena tidak adanya driver cadangan, dulu driver cadangan hampir 200 orang dan sekarang hanya tinggal sekitar $40 \%$ sampai dengan $50 \%$ saja.

Adanya sistem transportasi online ini sangat berpengaruh sekali bagi pihak kosti yaitu dimana sebelum adanya sistem online ini pihak taksi kosti ini menerima order melalui telepon yaitu sekitar 2 ribu per harinya melalui call center dan sekarang order melalui call center ini hanya sekitar 700 sampai dengan 800 order per harinya. Dengan keadaanya yang seperti ini pihak kosti mengikuti sistem yang sekarang sedang di butuhkan oleh masyarakat yaitu kosti bergabung sistem online yaitu gocar dan grab, dimana dari 225 armada yang ikut online sekitar $30 \%$ sampai dengan $40 \%$. Sebelum adanya sistem trasnportasi online yang di gemari masyarakat saat ini pihak kosti sudah mempunyai aplikasi online, namun aplikasi yang dimiliki oleh kosti kalah saing dengan aplikasi transportasi online yang sekarang.

Mengenai perlindungan hukum dalam hal pembiayaan ini telah ada dan diatur dalam perjanjian yang telah tercatat di notaris. Jadi pada intinya pembiayaan yang ada di koperasi sopir transportasi solo (kosti solo) ini adalah pihak kosti mengajukan pinjaman ke Bank Jateng dan apabila pengajuan pinjaman tersebut di setujui oleh pihak bank bpd maka pihak kosti akan menerima dana tersebut dan setelah itu pihak kosti membelikan barang modal 
dan kemudian akan di berikan kepada anggota untuk selanjutnya dilakukan dengan sistem perjanjian yang dimana anggota atau driver berkewajiban untuk melakukan setoran kepada pihak kosti dengan jumlah yang sudah di tentukan dan telah di sepakati dan kemudian pihak kosti yang memiliki kewajiban untuk membayarakan kepada pihak Bank Jateng, jadi semua beban dan resiko di tanggung seutuhnya oleh pihak kosti dan driver tidak bertanggung jawab dalam hal ini karena driver tidak berhubungan langsung dengan pihak perbankan tersebut. Sebelumnya jangka waktu yang diberikan atau yang telah di sepakati adalah 5 tahun per paketnya antara pihak kosti dan pihak Bank Jateng, namun dengan adanya keadaan yang sekarang ini yang menyebabkan pemasukan atau setoran pihak kosti berkurang atau menurun maka pihak kosti mengajukan permohonan kepada pihak bank bpd untuk perpanjangan jangka waktu per paketnya, dan pihak bank bpd memberikan respon yang positif dan menyutujui untuk memberikan perpanjangan waktu kepada pihak kosti menjadi 10 tahun jangka waktunya untuk per paketnya.

\section{Bisnis Transportasi dalam Pusaran Globalisasi}

GO-JEK didirikan oleh Nadiem Makarim, warga negara Indonesia lulusan Master of Business Administration dari Harvard Business School. Ide mendirikan GO-JEK muncul dari pengalaman pribadi Nadiem Makarim menggunakan transportasi ojek hampir setiap hari ke tempat kerjanya untuk menembus kemacetan di Jakarta. Saat itu, Nadiem masih bekerja sebagai Co-Founder dan Managing Editor Zalora Indonesia dan Chief Innovation Officer Kartuku. Sebagai seorang yang sering menggunakan transportasi ojek, Nadiem melihat ternyata sebagian besar waktu yang dihabiskan oleh pengemudi ojek hanyalah sekadar mangkal menunggu penumpang. Padahal, pengemudi ojek akan mendapatkan penghasilan yang lumayan bila banyak penumpang.

Pada tanggal 13 Oktober 2010, GO-JEK resmi berdiri dengan 20 orang pengemudi. Pada saat itu, GO-JEK masih mengandalkan call center untuk menghubungkan penumpang dengan pengemudi ojek. Pada pertengahan 2014, berkat popularitas Uber kala itu, Nadiem Makarim mulai mendapatkan tawaran investasi. Pada 7 Januari 2015, GOJEK akhirnya meluncurkan aplikasi berbasis Android dan IOS untuk menggantikan sistem pemesanan menggunakan call center. Gojek memperoleh pendanaan dari beberapa investor dari dalam maupun luar negeri diantaranya adalah

a. NSI Ventures. Besaran dana tidak dipublikasikan

b. Sequoia Capital dan DST Global. Besaran dana tidak dipublikasikan

c. KKR, Warburg Pincus, Farallon Capital dan Capital Group Private Markets. Besaran dana 7,2 T 
d. Google. Besaran dana 1,3 T

e. Tencent JD, Temasek dan Meituan Dianping. Besaran dana $16 \mathrm{~T}$

f. Astra Internasional. Besaran dana $2 \mathrm{~T}$

g. Djarum Grup. Besaran dana tidak dipublikasikan.

Setelah memperoleh pendanaan dari perusahaan perusahaan besar tersebut, GOJEK kemudian mengakuisisi "Silicon Valley" dan CodeIgnition dan Pianta dari India. Tidak puas dengan hal tersebut, Gojek lalu bertransformasi menjadi perusahaan financial technology (fintech) melalui GOPAY. Untuk meneguhkan eksistensinya dalam dunia baru tersebut, tak malu-malu GOJEK mengakuisisi Ponselpay, pemilik lisensi e-money dari Bank Indonesia. Berikutnya pada tahun 2017, Gojek mengambil alih tiga perusahaan fintech yaitu Kartuku, Midtrans dan Mapan. Sementara untuk menambah kekuatan GOTIX dibidang jual beli tiket, maka LOKET diambil alih. Tidak puas dengan kemampuan yang telah dimiliki, langkah selanjutnya adalah melakukan ekspansi ke Vietnam dengan mengakuisisi GO Ventures dan Coins dari Filipina senilai 1 Triliun. Sedangkan di lini berita Kumparan bersedia bergabung dengan GOJEK sehingga muncul layanan GO NEWS yang menampilkan berita dari Kumparan.com.

Melihat performa bisnis GOJEK yang terlihat cemerlang, maka timbul pertanyaan. Seriuskah GOJEK dengan bisnis transportasinya? Ataukah GOJEK adalah bisnis fintech dengan kedok perusahaan transportasi? Bagaimanakah pengaturan bisnis tersebut di Indonesia, apakah dibolehkan ditinjau dari hukum perizinan ataukah menyalahi aturan? Beragam pertanyaan lalu timbul melihat betapa mudahnya GOJEK memberikan diskon, potongan harga kepada consumer dengan alasan promo. Padahal namanya telah menasional secara luas bahkan telah mendunia dengan masuknya Google menjadi salah satu investornya. Pada tanggal 1 Februari 2019 ini tercatat, Google dan Tencent memberikan investasi sebesar US\$ 1 milyar atau senilai 14 Triliun. ${ }^{6}$

Gojek dan Grab menunjukkan persaingan yang sangat ketat. Hal ini kemudian mendorong pihak aplikator untuk menurunkan harga tarif dari ketentuan pemerintah. Pada tahun 2018, pemerintah mengusulkan bahwa tarif per $\mathrm{km}$ sebesar Rp. $2000^{7}$ namun pada Januari 2019 ini tarif Gojek masih 1.400 per km. Pemerintah mengusulkan tariff untuk taksi online sekitar Rp. 3500 per km namun belum disetujui oleh pihak aplikator. Terkait jam kerja para pengemudi, seringkali untuk mengejar point bonus mereka harus bekerja overtime. Hal ini tentu saja dapat membahayakan pengemudi maupun penumpang. Para pengemudi GOJEK itu dipotong $20 \%$ pendapatannya setiap kali transaksi. Bonus akan diberikan jika memenuhi target 16 transaksi setiap harinya. Hasilnya

${ }^{6}$ https:// www.cnbcindonesia.com/fintech/20190201103031-37-53439/lagi-tencent-dan-googlesuntik-modal-ke-gojek-rp-14-t

7 http:/ / kaltim.tribunnews.com/2018/03/30/mulai-pekan-depan-tarif-ojek-online-naik-cek-disini-daftar-harga-barunya?page $=2$ 
mereka akan berusaha memperoleh bonus dengan berbagai macam cara, bahkan dengan membuat transaksi palsu.

Pada tanggal 11 Januari 2019, Pemerintah bersiap memberlakukan peraturan untuk memperbaiki layanan ojek online seperti Grab dan Gojek termasuk menetapkan tarif tetap, sebagaimana yang telah disampaikan oleh Pejabat Kementrian Perhubungan. Sebelumnya Pemerintah telah menetapkan aturan terkait keberadaan taksi online dalam Peraturan Menteri Perhubungan No. 108 Tahun 2017. Namun Peraturan tersebut beberapa pasalnya dicabut setelah adanya pengajuan judicial review di Mahkamah Agung. Sebelumnya, Mahkamah Konstitusi (MK) menolak memasukkan angkutan berbasis sepeda motor itu masuk dalam Undang-undang Nomor 22 Tahun 2009 tentang Lalu Lintas dan Angkutan Jalan. Penolakan ini membuat Kementerian Perhubungan kini berencana mengalihkan regulasi soal ojek online ke pemerintah daerah. Penolakan Mahkamah dilakukan dalam sidang uji materi terhadap Pasal 138 ayat (3) dan Pasal 47 ayat (3) Undang-Undang (UU) Nomor 22 Tahun 2009 tentang Lalu Lintas dan Angkutan Jalan yang diajukan Komite Aksi Transportasi Online (KATO) yang mewakili 50 pemohon dari berbagai latar belakang profesi.

Dalam pertimbangannya, Hakim Konstitusi Arief Hidayat menilai bahwa legalitas ojek online bukan permasalahan konstitusional, sehingga tidak terkait dengan UU Lalu Lintas dan Angkutan Jalan. Mengetahui hal tersebut, KATO menyebut bahwa ketiadaan payung hukum terhadap keberadaan ojek online akan berdampak pada keselamatan pengemudinya. Menanggapi hal tersebut, Menteri Perhubungan sempat mengisyaratkan mengalihkan regulasi ojek online kepada Pemerintah Daerah, namun beberapa pengamat menilai, hal tersebut justru akan memicu konflik di tingkat daerah. ${ }^{8}$ Keberadaan transportasi online memang dirasakan manfaatnya di masyarakat. Diketahui bahwa ribuan orang menggantungkan nasib dengan mencari nafkah sebagai pengemudinya. Namun kesulitan Pemerintah mengaturnya tentu tidak lepas dari kuatnya hegemoni pemilik modal (pemilik usaha) dalam melakukan bargain dengan pemerintah. Ketika 18 Pasal dalam Peraturan Menteri Perhubungan tersebut dicabut, maka kewenangan Pemerintah untuk menghilangkan atau minimal mengurangi potensi konflik antara pemilik jasa transportasi konvensinal dan taksi online sulit tercapai.

Potensi konflik terbesar adalah terkait disparitas besaran tarif. Transportasi konvensional telah mengikuti alur yang sesuai dengan Pemerintah terkait trayek, plat nomer kuning, uji KIR kendaraan secara berkala, standarisasi pelayanan, perlindungan bagi pengemudi dan konsumen serta pajak. Sementara itu transportasi online mendobrak "kenyamanan" tersebut dengan munculnya kemudahan akses, tariff yang murah, program promo yang sering muncul serta kemudahan keikutsertaan menjadi pengemudinya. Tentu saja mereduksi

8https:/ / tirto.id/tarik-ulur-aturan-untuk-ojek-online-yang-berjalan-tanpa-kejelasan-cNfl 
standar yang telah ada selama ini. Sebagai contoh, keberadaan GOJEK yang terlihat memberikan diskon tariff secara besar-besaran dengan alasan promo tentu saja menmbulkan kecemburuan sosial diantara pengemudi taksi konvensinal. Sebagaimana diketahui bahwa penentuan harga tentulah berdasar pada biaya, permintaan dan ketersediaan jasa. Namun diketahui GOJEK dengan mudahnya mengenakan biaya Rp. 1000 (seribu rupiah) untuk layanannya.

\section{Kesimpulan}

Perbedaan antara taksi konvensional dan taksi online terletak pada besaran tariff, standarisasi layanan, penentuan trayek dan ciri khusus serta perlindungan hukum. Diperlukan segera ketegasan Pemerintah mengatur keberadaan transportasi online, mengingat potensi konflik atas disparitas perbedaan tariff dan pentingnya perlindungan hukum bagi pengemudi dan penumpang dalam keselamatan berkendara.

\section{REFRENCES}

Jaelani, A.K, Implementasi Daluarsa Gugatan Dalam Putusan Peradilan Tata Usaha Negara di Indonesia, Pena Justisia: Media Komunikasi dan Kajian Hukum. Volume 18, No. 2, 2019.

Hanum, W.N, Setting of Earth Oil Management in Old Wells Based on the Principle Social Justice, Jurnal Bestuur Vol. 8, Issue 2, December, 2020.

Intaniasari, Kirana, Gross Split Contract Framework Regulation on the Caring for People, Jurnal Bestuur Vol. 8, Issue 2, December, 2020.

Saputra, Rian, Development of Creative Industries as Regional Leaders in National Tourism Efforts Based on Geographical Indications, Jurnal Bestuur Vol. 8, Issue 2, December, 2020.

Akhmaddhian, Suwari. Discourse on Creating a Special Environmental Court in Indonesia to Resolve Environmental Disputes, Jurnal Bestuur Vol. 8, Issue 2, December, 2020.

Pane, E \& Yanis, A.M, Reconstruction of Mining Policies on Justice in Lampung Province, Jurnal Bestuur Vol. 8, Issue 2, December, 2020.

Gunawan, Said, The Principle of Control of Non Primary Gun System of the Indonesian National Army Protect Soldiers, Jurnal Bestuur Vol. 8, Issue 2, December, 2020.

Luthviati, R.D, The Role of Local Governments in the Defense of Leading Products, Jurnal Bestuur Vol. 8, Issue 2, December, 2020.

Abdul Kadir Jaelani, "Implementasi Daluarsa Gugatan Dalam Putusan Peradilan Tata Usaha Negara Di Indonesia", Jurnal Pena Justisia, Vol.18, Nomor 2 Tahun 2019.

Nurika Latiff Hikmawati "Efektivitas Penerapan Sanksi Pidana Penjara Terhadap Anak Yang Melakukan Tindak Pidana", Jurnal Pena Justisia, Vol.18, Nomor 2 Tahun 2019.

Miftahur Rahman Hakim, Nur Kholidah, "Hak Merek Sebagai Jaminan Gadai Untuk Permodalan Umkm Industri Kreatif Kerajinan Batik", Jurnal Pena Justisia, Vol.18, Nomor 2 Tahun 2019. 
Vidya Noor Rachmadini "Perlindungan Hukum Bagi Investor Dalam Pasar Modal Menurut Undang-Undang Pasar Modal Dan Undang-Undang Otoritas Jasa Keuangan", Jurnal Pena Justisia, Vol.18, Nomor 2 Tahun 2019.

Willy Naresta Hanum, "Setting of Earth Oil Management in Old Wells Based on the Principle Social Justice", Jurnal Bestuur, Volume 8, Nomor 2 Tahun 2020.

Resti Dian Luthviati, "The Role of Local Governments in the Defense of Leading Products", Jurnal Bestuur, Volume 8, Nomor 2 Tahun 2020. 